\title{
SYSTEM PRODUCTIVITY OF WHEAT- SESAME-T. AMAN RICE CROPPING PATTERN AS INFLUENCED BY VARIETAL REPLACEMENT
}

\author{
M. Maniruzzaman ${ }^{*}$, M. Robiul Alam¹, M. S. Islam¹, M. Z. Islam ${ }^{1}$ and M. A. Islam² \\ ${ }^{1}$ On-farm Research Division, Bangladesh Agricultural Research Institute, Pabna \\ ${ }^{2}$ On-farm Research Division, Bangladesh Agricultural Research Institute, Shampur, Rajshahi \\ "Corresponding author, E-mail: maniruzzaman.bari@yahoo.com
}

(Received: 21 December 2017, Accepted: 25 January 2018)

Keywords: Sustainable yield index, production efficiency, land use efficiency, rice equivalent yield

\begin{abstract}
The study was carried out at Multi Location Testing site, Sujanagar, Pabna during two consecutive years of 2011-12 and 2012-13 growing season to assess the performance of the pattern with newly released crop varieties against the existing one usually practiced by the farmers with traditional varieties in order to increase yield and economic return. The experiment was laid out in a randomized complete block design with six dispersed replications at farmer's field. In improved pattern (IP) BARI Gom-26, BARI Til-4 and Binadhan-7 variety were used for wheat, sesame and T. aman rice, respectively. On the contrary in existing pattern (EP) farmers usually use BARI Gom-21, local (char shira) and Sharna cultivar for wheat, sesame and $\mathrm{T}$. aman rice, respectively. The mean yield was recorded 4.66, 1.34 and $4.79 \mathrm{t} \mathrm{ha}^{-1}$ from wheat (BARI Gom-26), sesame (BARI Til-4) and T. aman (Binadhan-7) respectively from the improved cropping pattern whereas average yield 3.81, 0.98 and $4.58 \mathrm{t} \mathrm{ha}^{-1}$ was obtained from wheat (BARI Gom-21), sesame (local) and T. aman (Sharna), respectively from the existing pattern. Two years mean data also showed that improved pattern provided about 18\% higher REY compared to existing pattern. Sustainable yield index and production efficiency were also found maximum with improved cropping pattern. Similarly, maximum gross margin and benefit cost ratio were obtained from improved cropping pattern.
\end{abstract}

\section{Introduction}

The major cropping pattern in Bangladesh agriculture mostly consist of rice based cereal crops. Cropping pattern is the yearly sequence, temporal and spatial arrangement of crops in a given crop field. A cropping pattern on an area largely depends on some factors like climate, type of soil, rainfall, agricultural technology, irrigation facilities, different inputs, marketing, transport facilities and growth of agro-industries (Neena, 1998; Gadge, 2003). An effective cropping pattern ensures the best efficiency of land, labor, fertilizer, irrigation water and other inputs (Harwood, 1974). Wheat-Sesame-T. aman rice is one of the most popular and important cropping pattern in Pabna region. But total productivity from this cropping patter is very much low.

The causes of lower yield of the crops under Wheat-Sesame-T. aman rice are mainly because the farmers' of that locality use old traditional varies of wheat, sesame and T. aman rice. Those old traditional crop varieties are low yield potential, insect and disease susceptible. The farmers harvest poor yield from 
local and old varieties that can be increased manifold by introducing high yielding modern varieties (Alam and Rahman, 2006; Basak et al., 2007). Therefore, the study was undertaken to assist the farmers in the drought prone areas to increase their income using proper cropping pattern with modern high yielding crop varieties.

\section{Materials and Methods}

The study was carried out at Multi Location Testing site, Sujanagar, Pabna during two consecutive years of 2011-12 and 2012-13 growing season to assess the performance of the pattern with newly released crop varieties against the existing one usually practiced by the farmers with traditional varieties in order to increase yield and economic return. High yielding modern varieties of wheat, sesame and $T$. aman were advised to be included in place of traditional local varieties usually cultivated by farmers. Wheat (BARI Gom-26), sesame (BARI Til-4) and $\mathrm{T}$. aman (Binadhan-7) were selected for inclusion in the improved pattern against wheat (BARI Gom-21), local sesame (charshira) and Sharna as T. aman used to be cultivated by the farmers in their traditional existing cropping pattern. The experiment was laid out in a randomized complete block design with six dispersed replications at farmer's field.

The agronomic practices and cultural operation of crop production under improved and existing cropping patterns are presented in Table 1. All field operation and management practices were closely monitored. Yield and other relevant data were recorded carefully to make a comparison between the improved and existing pattern regarding yield and economic return. Agronomic performance viz. production efficiency, rice equivalent yield (REY) and sustainable yield index (SYI) of cropping patterns were calculated by the following formula:

\section{Production efficiency}

Production efficiency values in terms of $\mathrm{kg} \mathrm{ha}^{-1}$ day ${ }^{-1}$ were calculated by total production in a cropping sequence divided by total duration of crops in that sequence (Tomer and Tiwari. 1990).

$$
\text { Production efficiency }=\frac{Y_{1}+Y_{2}+Y_{3}}{d_{1}+d_{2}+d_{3}}
$$

Where, $Y_{1}=$ Yield of 1 st crop and $d_{1}=$ Duration of 1 st crop of the pattern $Y_{2}=$ Yield of 2 nd crop and $\mathrm{d}_{2}=$ Duration of 2 nd crop of the pattern $\mathrm{Y}_{3}=$ Yield of 3rd crop and $\mathrm{d}_{3}=$ Duration of 3rd crop of the pattern

\section{Sustainable yield index (SYI)}

Sustainable yield index was worked out by the following formula suggested by Krishna and Reddy (1997).

$$
\text { Sustainable yield index }(\mathrm{SYI})=\frac{Y_{\text {mean }}-S D}{Y_{\max }} \times 100
$$

Where, Y mean: Estimated mean yield of a practice over years; SD: Estimated standard deviation; $\mathrm{Y}$ max: Observed maximum yield in the experiment over the years.

\section{Rice Equivalent Yield (REY)}

For comparison between crop sequences, the yield of all crops was converted into rice equivalent on the basis of prevailing market price of individual crop (Verma and Mongal, 1983). The economic indices like Gross return and net 
return and benefit cost ratio were also calculated on the basis of prevailing market price of the produces.

Rice equivalent yield $=$

For economic evaluation of two different cropping sequences averaged data of two crop cycles were used. The gross cost of cultivation of different crops was calculated on the basis of different operations performed and materials used for raising the crops. Gross margin, gross return and total cost of cultivation of the crops were calculated as well as benefit cost ratio (BCR) as per following formula:

Benefit cost ratio $(\mathrm{BCR})=$ Gross return $\left(\mathrm{Tk} . \mathrm{ha}^{-1}\right) /$ Total variable cost $\left(\mathrm{Tk} . \mathrm{ha}^{-1}\right)$

Table 1. Management practices of improved and existing cropping pattern

\begin{tabular}{|c|c|c|c|}
\hline Parameters & Crops & Improved pattern (IP) & Existing pattern (EP) \\
\hline \multirow{3}{*}{ Variety } & Wheat & BARI Gom-26 & BARI Gom-21 \\
\hline & Sesame & BARI Til-4 & Local charshira \\
\hline & T. aman & Binadhan-7 & Sharna \\
\hline \multirow{3}{*}{$\begin{array}{l}\text { Sowing/Transplanting } \\
\text { time }\end{array}$} & Wheat & 30 November to 5 December & \\
\hline & Sesame & 16 to 24 April & \\
\hline & T. aman & 7 to 13 August & \\
\hline \multirow{3}{*}{ Planting method } & Wheat & Line sowing & Broadcasting \\
\hline & Sesame & Line sowing & Broadcasting \\
\hline & T. aman & Line sowing & Line sowing \\
\hline \multirow{3}{*}{$\begin{array}{l}\text { Fertilizer dose } \\
\text { (N-P-K-S-Zn-B kg ha' } \\
\text { 1) }\end{array}$} & Wheat & $83-28-20-20-3-2.5$ & \\
\hline & Sesame & $48-27-23-18-0-0$ & \\
\hline & T. aman & 69-22-35-11-3.6-1.4 & \\
\hline \multirow{3}{*}{ Weeding (no) } & Wheat & 1 & 1 \\
\hline & Sesame & 1 & 1 \\
\hline & T. aman & 2 & 2 \\
\hline \multirow{3}{*}{ Irrigation/Rainfed } & Wheat & 2 & 2 \\
\hline & Sesame & Rainfed & Rainfed \\
\hline & T. aman & 2 & 2 \\
\hline \multirow{3}{*}{ Harvesting time } & Wheat & 17 to 25 March & 20 to 28 March \\
\hline & Sesame & 18 to 28 July & 14 to 23 July \\
\hline & T. aman & 2 to 10 November & 20 to 26 November \\
\hline \multirow{3}{*}{ Field duration (days) } & Wheat & $108-112$ & $111-115$ \\
\hline & Sesame & $94-96$ & $90-92$ \\
\hline & T. aman & $88-92$ & $106-110$ \\
\hline
\end{tabular}

\section{Results and Discussion}

Grain and straw yield of the pattern

Grain and straw yield of wheat, sesame and $T$. aman rice of both the cropping patterns are presented in Table 2. It was observed that wheat, sesame and $\mathrm{T}$. aman rice under improved cropping pattern perform significantly higher than that of existing cropping pattern in both the year. In case of wheat the mean grain yield of BARI Gom-26 (4.66 $t$ ha $^{-1}$ ) was found higher than BARI Gom-21 (3.81 $\left.\mathrm{t} \mathrm{ha}^{-1}\right)$. The seed yield of BARI Til-4 (1.34 $\left.\mathrm{t} \mathrm{ha}^{-1}\right)$ was also found higher than local sesame cultivar $\left(0.98 \mathrm{t} \mathrm{ha}^{-1}\right)$. In case of $\mathrm{T}$. aman rice yield of Binadhan-7 (4.79 $\mathrm{t} \mathrm{ha}^{-1}$ ) was found higher compare to local cultivar Sharna (4.58 $\left.\mathrm{t} \mathrm{ha}^{-1}\right)$. Similar trend was found in case of straw yield except $\mathrm{T}$. aman rice where local cultiver Sharna provided higher straw yield compared to Binadhan-7. In both the 
year improved pattern performed better than the existing cropping pattern. This might be due to use of high yielding modern crop varieties in improved cropping pattern. On the contrary the verities used in existing cropping pattern are low yielder, insect and disease susceptible. This result was supported by the results of Nazrul (2016), Nazrul et al. (2013), Khan et al. (2005) and Hossain and Wahhab (1992)

Table 2. Grain and straw yield of different crops obtained from improved pattern (IP) and existing pattern (EP) during 2011 to 2013

\begin{tabular}{clcccccc}
\hline \multirow{2}{*}{ Years } & \multicolumn{2}{c}{$\begin{array}{c}\text { Cropping } \\
\text { patterns }\end{array}$} & \multicolumn{3}{c}{ Grain yield $\left(\mathrm{t} \mathrm{h} \mathrm{h}^{-1}\right)$} & \multicolumn{3}{c}{ Straw yield $\left(\mathrm{t} \mathrm{ha}^{-1}\right)$} \\
\cline { 3 - 8 } & Wheat & Sesame & $\mathrm{T}$. aman & Wheat & Sesame & T. aman \\
\hline \multirow{5}{*}{$2011-12$} & IP & 4.56 & 1.36 & 4.81 & 5.54 & 4.8 & 6.5 \\
& EP & 3.87 & 1.0 & 4.65 & 4.5 & 3.0 & 6.86 \\
& t value & 28.327 & 12.198 & 2.701 & 26.501 & 12.198 & -4.309 \\
& Level of & $* *$ & $* *$ & $*$ & $* *$ & $* *$ & $* *$ \\
& significance & & & & & & \\
& IP & 4.75 & 1.32 & 4.76 & 5.69 & 4.6 & 6.25 \\
& EP & 3.75 & 0.95 & 4.5 & 4.3 & 2.75 & 6.66 \\
$2012-13$ & t value & 387.29 & 24.222 & 71.204 & 380.67 & 270.81 & -44.041 \\
& Level of & $* *$ & $* *$ & $* *$ & $* *$ & $* *$ & $* *$ \\
& significance & & & & & & \\
\hline \multirow{2}{*}{ Mean } & IP & 4.66 & 1.34 & 4.79 & 5.62 & 4.7 & 6.38 \\
& EP & 3.81 & 0.98 & 4.58 & 4.43 & 2.88 & 6.76 \\
\hline
\end{tabular}

$\mathrm{IP}=$ Improved pattern, $\mathrm{EP}=$ Existing pattern.

$*$ Significance at $5 \%$ level and ${ }^{* *}=$ Significance at $1 \%$ level

\section{Rice equivalent yield}

Rice equivalent yield of improved cropping pattern was found higher compared to existing cropping pattern in both the years (Table 3). The mean rice equivalent yield $14.24 \mathrm{t} \mathrm{ha}^{-1}$ was obtained from improved pattern which was about $18 \%$ higher than existing pattern. This higher rice equivalent yield was might be due to inclusion of high yielding modern varieties in improved cropping pattern.

\section{Production efficiency}

Higher production efficiency was found from improved cropping pattern in both the year as compared to existing cropping pattern (Table 3). The mean production efficiency of $38.56 \mathrm{~kg} \mathrm{ha} \mathrm{hay}^{-1}$ was obtained from improved pattern which was about 26\% higher than existing pattern. This higher production efficiency was might be due to higher yield of modern varieties in improved cropping pattern. Similar results were also observed by Nazrul (2016), Nazrul et al. (2013) and Khan et al. (2005).

\section{Sustainable yield index}

Maximum sustainable index was also found from improved cropping pattern in both the years as compared to existing cropping pattern (Table 3). The mean sustainable yield index (68.25\%) was obtained from improved pattern which was about $41 \%$ higher than existing pattern.

Table 3. Rice equivalent yield, Production efficiency and Sustainable yield index obtained from improved pattern (IP) and existing pattern (EP) during 2011 to 2013

\begin{tabular}{ccccc}
\hline Years & $\begin{array}{c}\text { Cropping } \\
\text { patterns }\end{array}$ & $\begin{array}{c}\text { Rice equivalent } \\
\left.\text { yield }(\mathrm{t} \mathrm{ha})^{-1}\right)\end{array}$ & $\begin{array}{c}\text { Production efficiency } \\
\left(\mathrm{kg} \mathrm{ha}^{-1} \text { day }^{-1}\right)\end{array}$ & $\begin{array}{c}\text { Sustainable } \\
\text { yield index }(\%)\end{array}$ \\
\hline $2011-12$ & IP & 14.22 & 48.53 & 70.95
\end{tabular}




\begin{tabular}{lcccc}
\multirow{2}{*}{$2012-13$} & EP & 12.25 & 39.26 & 48.71 \\
\multirow{2}{*}{ Mean } & IP & 14.26 & 48.67 & 66.01 \\
& EP & 11.81 & 37.85 & 47.84 \\
& IP & 14.24 & 48.60 & 68.25 \\
\hline \multicolumn{2}{c}{$\%$ increase over EP } & 12.03 & 38.56 & 48.28 \\
\hline
\end{tabular}

$\mathrm{IP}=$ Improved pattern, $\mathrm{EP}=$ Existing pattern, Price: of Rice $=18 \mathrm{Tk} . \mathrm{kg}^{-1}$; Wheat $=20 \mathrm{Tk}$. $\mathrm{kg}^{-1} ;$ Mustard $=45 \mathrm{Tk} . \mathrm{kg}^{-1}$

\section{Cost and Return Analysis}

Between two cropping patterns, the improved pattern provided more profit over existing pattern during two consecutive cropping years (Table 4). The mean gross return obtained from improved pattern (Tk. 2,56,320 ha-1) was higher than that of existing cropping pattern (Tk. 2,16,540 ha ${ }^{-1}$ ). Higher gross margin was obtained from improved cropping pattern which was Tk. 13,94,465 ha ${ }^{-1}$ against total variable cost of Tk. 1,21,855 $\mathrm{ha}^{-1}$ whereas existing pattern provided lower gross margin which was Tk. 97,090 ha $^{-1}$ against total variable cost of $\mathrm{Tk}$. $1,19,450 \mathrm{ha}^{-1}$. Maximum BCR was also recorder from improved pattern (2.10) and minimum from existing pattern (1.81).

Table 4. Cost and return of improved and existing cropping pattern during 2011 to 2013

\begin{tabular}{cccccc}
\hline Years & $\begin{array}{c}\text { Cropping } \\
\text { patterns }\end{array}$ & $\begin{array}{c}\text { Gross return } \\
\left(\text { Tk. ha }{ }^{-1}\right)\end{array}$ & $\begin{array}{c}\text { Total variable } \\
\text { cost }(\text { Tk. ha } \\
\text { 1) }\end{array}$ & $\begin{array}{c}\text { Gross margin } \\
\left(\text { Tk. ha }{ }^{-1}\right)\end{array}$ & BCR \\
\hline \multirow{2}{*}{$2011-12$} & IP & 255960 & 121230 & 134730 & 2.11 \\
& EP & 220500 & 118850 & 101650 & 1.85 \\
$2012-13$ & IP & 256680 & 122480 & 134200 & 2.10 \\
\multirow{2}{*}{ Mean } & EP & 212580 & 120050 & 92530 & 1.77 \\
& IP & 256320 & 121855 & 134465 & 2.10 \\
\hline
\end{tabular}

$\mathrm{IP}=$ Improved pattern, $\mathrm{EP}=$ Existing pattern. Price of rice seed $=18 \mathrm{Tk} . \mathrm{kg}^{-1}$; Wheat seed $=$ $20 \mathrm{Tk} . \mathrm{kg}^{-1}$; Mustard seed $=45 \mathrm{Tk} \cdot \mathrm{kg}^{-1}$ and all straw $=1 \mathrm{Tk} . \mathrm{kg}^{-1}$

\section{Conclusion}

Wheat-Sesame-T. aman rice is one of the major cropping patterns in Pabna region. This pattern could be more productive, sustainable and profitable if farmer cultivated modern high yielding varieties of wheat, sesame and $T$. aman rice. Therefore, the farmers of this locality should cultivate BARI Gom-26, BARI Til-4 and Binadhan-7 instead of BARI Gom-21, local charshira sesame and local cultiver Sharna in their Wheat-Sesame-T. aman rice cropping pattern for higher system productivity and profitability.

\section{References}

Alam, M. M. and M. M. Rahman. 2006. Effect of row spacing on seed yield of five varieties of Rapeseed. Bangladesh J. Crop Sci. 17(1): 163-168. 
Basak, N. C., J. C, Pandit and M. H. Khurram. 2007. On-farm evaluation of three mustard varieties under different fertilizer packages. Bangladesh J. Sci. Ind. Res. 42(3): 335-340.

Gadge, S. S. 2003. Influence of changes in cropping pattern on farmers' economic status. Indian J. Ext. Edu. 39(1 and 2): 99-101.

Harwood, R.R. 1974. Resource utilization approach to cropping system improvement. International workshop on Farming Systems, 18-21 November 1974, ICRISAT, Hydarabad, India.

Hossain, M. A. and M. A. Wahhab. 1992. Demonstration cum assessment of recommended and farmer's technologies in jute cultivation. Abs. of Research. Agril. Res. on Jute, Bangladesh Jute Research Institute: p. 250.

Khan, M. A., M. A. Quayyum, M. I. Nazrul, N. Sultana and M. R. A. Mollah. 2005. On-farm evaluation of production potential and economics of mustardrice based improved cropping system. J. Socio. Res. Dev. 2(1): 37-42.

Krishna, A. and K. A. Reddy. 1997. Production potential and economics of rice based cropping system in Andhra Pradesh. Indian J. Agril. Sci. 67(12): 551553.

Nazrul, M. I. 2016. On-farm assessment of system productivity of Wheat- Jute- T. aman rice cropping pattern in Sylhet region. Bangladesh Agron. J. 19(2): 8794.

Nazrul, M. I., M. R. Shaheb, M. A. H. Khan and A. S. M. M. R. Khan. 2013. On-farm evaluation of production potential and economic returns of potatorice based improved cropping system. Bangladesh Agron. J. 16(2): 51-50.

Neena, D. 1998. Interstate variation in cropping pattern in India. Indian J. Regi. Sci. 30(2): 57-69.

Tomer, S. S. and A. S. Tiwari. 1990. Production potential and economics of different crop sequences. Indian J. Agron. 35(1, 2): 30-35.

Verma, S. P. and S. C. Mongal. 1983. Production potential and economics of fertilizer application as resources constraints in maize, wheat crop sequence. Himachal J. Agric. Res. 9(2): 89-92. 